\title{
Understanding how changing soil nitrogen affects plant-pollinator interactions
}

\author{
Thomas I. David ${ }^{1,2}$ (]) Jonathan Storkey ${ }^{1} \cdot$ Carly J. Stevens $^{2}$
}

Received: 14 November 2018 / Accepted: 14 August 2019 / Published online: 23 August 2019

(c) The Author(s) 2019

\begin{abstract}
Many pollinating insects, across taxa and regions, have declined during the twentieth century. Amongst the drivers of these trends, soil eutrophication and acidification caused by nitrogen $(\mathrm{N})$ have not been broadly researched. Anthropogenic influences have greatly increased the global deposition of $\mathrm{N}$ to soils during the past century; this is increasingly recognised as a threat to global biodiversity. The fundamental role of soil in plant growth and health means that alterations to soil conditions will likely have consequences for plant-pollinator interactions. Soil $\mathrm{N}$ can be a substantial driver of the species structure of botanical communities, often reducing species richness due to quick growth of competitive grasses. Floral traits, relevant to pollinators, such as phenology, morphology, and nectar and pollen production and quality can also be affected by soil $\mathrm{N}$. We currently lack sufficient research to determine if and how pollinators will be impacted by these changes. This review collates the research and evidence of how soil $\mathrm{N}$ affects botanical species composition and relevant floral traits, and discusses how pollinating insects and plant-pollinator interactions might be impacted. We conclude by identifying the key knowledge gaps in this subject; the lack of research that includes the pollinators into studies of how $\mathrm{N}$ additions affect botanical traits, poor understanding of inter-specific variation in botanical responses to $\mathrm{N}$, synthesis of botanical traits to form a comprehensive understanding, and the inclusion of other abiotic and biotic drivers into studies.
\end{abstract}

Keywords Nitrogen deposition $\cdot$ Soil nitrogen $\cdot$ Floral traits $\cdot$ Pollinators $\cdot$ Plant-pollinator interactions

\section{Introduction}

The life cycles of pollinating insects are sustained through flowering plants, which provide nutrition for adults and their progeny. Through this interaction, environmental impacts on plants can have consequences for pollinators, and vice versa; if pollinators are affected it can have further implications for the quality of pollination services delivered to entomophilous plants (Fontaine et al. 2006; Fründ et al. 2013). Plant-pollinator interactions are vital in supporting terrestrial biodiversity and the functional stability of ecosystems; it is estimated that $87.5 \%$ of global plant species

Communicated by Isabel Alves dos Santos.

Thomas I. David

thomas.david@rothamsted.ac.uk

1 Sustainable Agriculture Sciences, Rothamsted Research, West Common, Harpenden AL5 2JQ, UK

2 Lancaster Environment Centre, Lancaster University, Lancaster LA1 4YQ, UK rely on biotic pollination (Ollerton et al. 2011). Pollinators are also important for the yields of many agricultural crops (Gallai et al. 2008; Garibaldi et al. 2011, 2014; Rader et al. 2016); 87 of the 115 leading global food crops, accounting for $35 \%$ of our agricultural produce, rely on biotic pollination (Klein et al. 2007). Insects are the key pollinators in most systems (Gallai et al. 2008; Patiny et al. 2009; Potts et al. 2010; Wardhaugh 2015; Ollerton 2017). However, it is well documented that insect pollinators are in decline across a range of taxa and ecoregions, due to a combination of factors that include habitat degradation, land-use change, parasites, pesticides, and the transport of non-native commercial pollinators (e.g. Williams and Osborne 2009; Potts et al. 2010; Winfree et al. 2011; Vanbergen and Iniative 2013; Rundlöf et al. 2015). Soil eutrophication, caused by atmospheric nitrogen deposition and increased use of inorganic and organic fertilisers, is known to contribute to declining habitat quality. However, the effect of elevated biologically available nitrogen $(\mathrm{N})$ on plant-pollinator interactions has received very little research attention (Harrison and Winfree 2015). 
Excessive soil enrichment with $\mathrm{N}$ can occur through fertiliser application, agricultural run-off, and through atmospheric $\mathrm{N}$ deposition. The increase in $\mathrm{N}$, often a limiting nutrient, typically boosts above-ground primary productivity, which favours fast-growing, nitrophilic plants. This leads to taller vegetation and creates stronger competition for light, with smaller and slower growing species often suffering as a result (Mountford et al. 1993; Crawley et al. 2005). Anthropogenically increased deposition of $\mathrm{N}$ to soils has distorted the $\mathrm{N}$ cycle and causes excessive soil $\mathrm{N}$. This is now recognised as a substantial threat to global biodiversity (Phoenix et al. 2006; Bobbink et al. 2010; Bleeker et al. 2011; Erisman et al. 2014; Schoukens 2017). We have an increasingly well-developed understanding of how plant communities respond to $\mathrm{N}$ deposition (Bobbink et al. 2010). However, evidence on the consequential impacts to further trophic levels is lacking (Stevens et al. 2018). Research on plant-herbivore and plant-herbivore-predator interactions demonstrates that soil $\mathrm{N}$ affects invertebrate development and populations (e.g. Jefferies and Maron 1997; Haddad et al. 2000; Throop and Lerdau 2004; Aqueel and Leather 2012; Banfield-Zanin et al. 2012; Pöyry et al. 2017). We urgently need to understand how pollinators are responding to the changing environment caused by $\mathrm{N}$ deposition to aid our knowledge of pollinator declines and mitigate adverse consequences in the future.

Soil eutrophication can impact plants in various ways, such as by altering soil microbial communities (e.g. Farrer and Suding 2016), increasing their susceptibility to pests and pathogens (e.g. Brunsting and Heil 1985; Strengbom et al. 2003, 2006), and interacting with other environmental drivers and stressors (e.g. Caporn et al. 2000; Tylianakis et al. 2008). However, this review will address the most widespread impacts: chronic eutrophication and, in poorly buffered soils, acidification (Bobbink et al. 1998). The review will begin by introducing the recent history of anthropogenic alterations of the $\mathrm{N}$ cycle. The second part will discuss how relevant botanical traits are impacted by $\mathrm{N}$ additions, and how this might affect pollinators and their interactions with plants. The review will conclude by identifying key knowledge gaps in this research area.

\section{Historic nitrogen production and deposition}

Humans have dramatically altered the $\mathrm{N}$ cycle, mostly through agricultural and energy industries (Vitousek et al. 1997; Cornell et al. 2003; Galloway et al. 2004; Fowler et al. 2013; Erisman et al. 2014). Global anthropogenic $\mathrm{N}$ production increased from $15 \mathrm{Tg} \mathrm{N}$ year ${ }^{-1}$ in 1860 to $187 \mathrm{Tg} \mathrm{N}$ year $^{-1}$ in 2005 (Galloway et al. 2008) and is now the dominant supply of biologically available $\mathrm{N}$ to soils. Global atmospheric N deposition consequentially increased from $34 \mathrm{Tg} \mathrm{N}$ year $^{-1}$ in 1860 to $100 \mathrm{Tg} \mathrm{N}_{\text {year }}{ }^{-1}$ in 1995 and is estimated to double between 1995 and 2050 (Galloway et al. 2004). Global fertiliser production saw a large increase during the twentieth century (Newbould 1989). Inorganic fertiliser application increased in Europe during the last century, although some countries have decreased application since the 1980's (Stoate et al. 2001).

Atmospheric $\mathrm{N}$ deposition is currently highest in the developed temperate regions of the Northern Hemisphere (Dentener et al. 2006; Bleeker et al. 2011). Since the 1980 's, the deposition rate in Europe and North America has begun to level off and decrease in some areas, due to more efficient technologies and the plateauing of $\mathrm{N}$ fertiliser application (Cornell et al. 2003; Goulding et al. 2015); at current levels it is typically $10-25 \mathrm{~kg} \mathrm{~N}$ $\mathrm{ha}^{-1}$ year $^{-1}$ (Bleeker et al. 2011; Dentener et al. 2006). In many ecosystems, this still falls above the estimated critical threshold for sensitive ecosystems of $15 \mathrm{~kg} \mathrm{~N} \mathrm{ha}^{-1}$ year $^{-1}$ (Phoenix et al. 2006). In China, the rate can exceed $50 \mathrm{~kg} \mathrm{~N} \mathrm{ha}^{-1}$ year $^{-1}$ and is increasing (Liu et al. 2013). Atmospheric $\mathrm{N}$ deposition is typically lower in remote undeveloped areas of the Southern Hemisphere, although the rate is expected to increase dramatically in the future (Dentener et al. 2006; Galloway et al. 2008). This is concerning, as many of the world's biodiversity hotspots are found in the Southern Hemisphere and will be in danger of rising levels of $\mathrm{N}$ deposition in excess of the critical thresholds of sensitive ecosystems (Phoenix et al. 2006; Bleeker et al. 2011).

Baude et al. (2016) suggested that trends in UK pollinator diversity may be directly related to atmospheric $\mathrm{N}$ deposition during the past century. From the early twentieth century until approximately the 1980's, atmospheric $\mathrm{N}$ deposition increased (Fowler et al. 2004; RoTAP 2012; Storkey et al. 2015) while total nectar provision, nectar diversity and pollinator diversity all decreased (Carvalheiro et al. 2013; Baude et al. 2016). Since the 1990's, when N deposition in the UK began to plateau and decline, nectar diversity and total nectar provision increased alongside an alleviation in the decline of pollinator diversity (Carvalheiro et al. 2013; Baude et al. 2016). Research into the relationship between $\mathrm{N}$ deposition and plant-pollinator interactions and pollinator assemblages is required to determine if these correlative trends need to be considered more meaningfully in pollinator debates. With more data and evidence, we can begin to develop a mechanistic understanding of how pollinators are affected by changes in soil $\mathrm{N}$ across taxa and ecoregions in the context of the multitude of other factors impacting pollinator populations (Vanbergen and Iniative 2013). Long-term ecological experiments such as the Park Grass Experiment at Rothamsted Research (Hertfordshire, UK) have an important role to play in elucidating these mechanisms (Storkey et al. 2016). 


\section{Pathways of how $\mathbf{N}$ impacts on pollinators}

When pollinating insects forage in the natural world, they choose from a selection of floral resources, dependent on the season and flowering phenology. Floral morphology can serve to attract, or restrict, potential flower visitors. The key rewards that pollinating insects seek are nectar and pollen; the nutritional qualities, tastes, and scents of these floral rewards affect the health of pollinators and can attract or repel floral visitors. These aspects of plant-pollinator interactions clearly set out the various trait pathways through which $\mathrm{N}$-driven changes to botanical communities affect plant-pollinator interactions: (1) species composition, (2) phenology, (3) partitioning of resources to flowers and floral morphology, and (4) the quantity and nutritional quality of nectar and pollen (Fig. 1). The increased availability of N, commonly a limiting nutrient, can potentially alter relevant botanical traits. Therefore, $\mathrm{N}$ addition could disrupt or, conversely, strengthen individual plant-pollinator interactions, possibly affecting the structure of networks, and pollinator communities. The following sections will review the scientific evidence for the effects of $\mathrm{N}$ on these botanical traits, in addition to how insect pollinators may be affected by the disturbances to these traits (Fig. 1).

\section{Species composition}

Soil eutrophication lessens the limitation of a key resource nutrient; consequentially altering plant competition dynamics, typically causing increased biomass of fast-growing competitive grasses at the expense of flowering forbs and legumes (e.g. Suding et al. 2005; Helsen et al. 2014; Goulding et al. 2015; Storkey et al. 2015). Soil acidification reduces $\mathrm{pH}$, frees potentially toxic heavy metals such as aluminium, and decreases the cation-exchange capacity and availability of beneficial minerals (Stevens et al. 2010b; Phoenix et al. 2012). This causes further selectivity, with plants sensitive to low $\mathrm{pH}$ and heavy metals, such as aluminium, declining (Stevens et al. 2010b), especially in poorly buffered soils such as acidic grasslands, heaths, and forests (Clark et al. 2007; Diekmann et al. 2014; Field et al. 2014). Therefore, soil eutrophication and acidification are important drivers of reduced botanical species richness (e.g. Stevens et al. 2010a, b; Duprè et al. 2010; Wesche et al. 2012; Field et al. 2014). However, even when species richness does not decrease there can be shift in botanical community structure and a decline in flowering forbs, reducing the richness of useful species for pollinators and other flower visiting insects (Phoenix et al. 2012).

The dominance of grasses tolerant to $\mathrm{N}$ and low $\mathrm{pH}$ translates into reduced diversity and abundance of plants that provide nectar and pollen for pollinators (Wesche et al. 2012; Helsen et al. 2014). Habitat degradation and the loss of entomophilous plants is known to be a key factor in insect

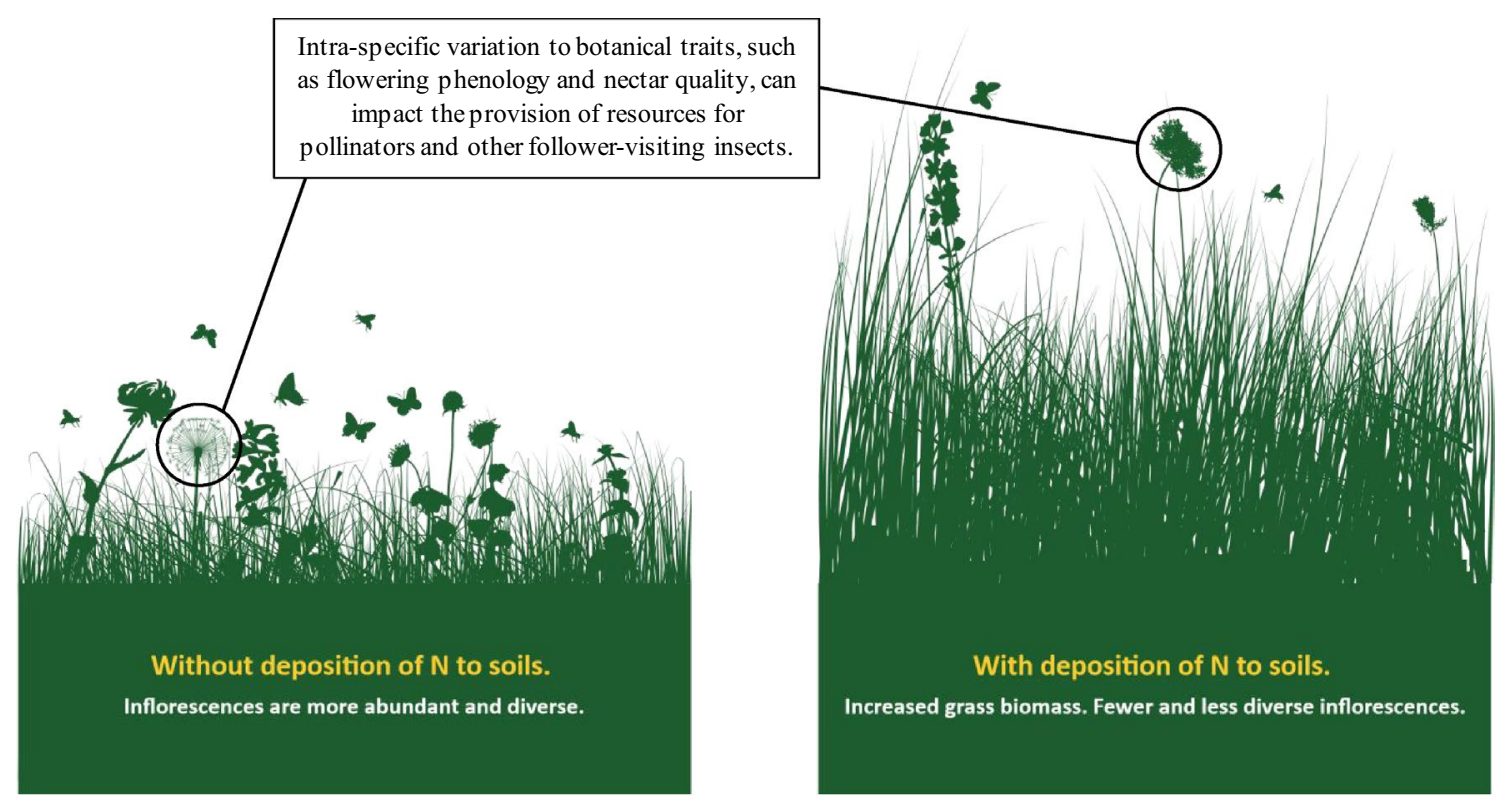

Fig. $1 \mathrm{~N}$ deposition alters the landscape and can affect the available food resources for pollinators. The image depicts the loss of flowering species and dominance of grasses with elevated $\mathrm{N}$ deposition. Our understanding of the impacts to floral traits, such as phenology, morphology, nectar and pollen is lacking 
declines (e.g. González-Varo et al. 2013). The loss of nectar and pollen resources are a detriment for current and future generations of pollinator communities. Biesmeijer et al. (2006) found a correlation between declining pollinator diversity and the loss of nectar and pollen resources in Britain and the Netherlands, although this study did not explore causality.

Evidence from temperate and montane grasslands suggests that the rate of botanical species loss increases with higher levels of $\mathrm{N}$ deposition (Stevens et al. 2010a; Humbert et al. 2016). Therefore, the impact to pollinators may be more severe at greater deposition levels. In the Northern Hemisphere, where $\mathrm{N}$ deposition has been high, this may have contributed to the negative trends of many insect pollinators during the twentieth century (Wallisdevries et al. 2012; Carvalheiro et al. 2013), as suggested by Baude et al. (2016).

Studies from Mediterranean and tropical ecosystems show $\mathrm{N}$ deposition can encourage the spread of exotic nitrophilic plant species at the expense of native forbs (Bobbink et al. 2010). Encroachment of exotic grasses could greatly harm the native pollinator community by decreasing native nectar and pollen resources. The invasion of exotic entomophilous plants can have more complex dynamics for pollinator communities and the consequences will likely vary with botanical species and invaded community (Bartomeus et al. 2008). The additional nectar and pollen resources can be beneficial for flower visitors and attract many generalist pollinating insects. However, invasive plant species can compete with native species and potentially dominate pollen transport networks, which threatens the reproduction of native plant species (Lopezaraiza-Mikel et al. 2007). While generalist insect pollinators may benefit, there is a concern that specialised native pollinators will suffer if their associated food plants decline (Weiss 2009).

There is a large diversity of plant-pollinator interactions, with plants and pollinators adapting specialised traits to improve the efficiency of their interaction. Insect pollinators occupy a range of niches and can be categorised into functional groups that reflect size, feeding apparatus, and foraging behaviours. Some functional groups are linked with certain functional groups of floral traits, such as long-tongued bees and the deep corollas of Trifolium pratense. To understand more accurately how soil-driven shifts in plant community composition affect pollinating insects, we need to know how specific plant functional groups, species, and traits within a community respond. The loss of certain botanical species and traits threatens specialist interactions and is a cause of historic pollinator loss (Kleijn and Raemakers 2008; Scheper et al. 2014). For example, in the Netherlands, declines in N-sensitive host plants have led to the local extinctions of their associated butterfly species (Öckinger et al. 2006). Meanwhile, butterflies that utilise nitrophilic host plants are increasing in abundance (Wallisdevries et al. 2012; WallisDeVries and van Swaay 2017). The high levels of $\mathrm{N}$ deposition in Harpenden, UK during the 1970-1980's dramatically reduced the ability of Fabaceae, such as Trifolium pratense, to grow naturally (Storkey et al. 2015). Since the 1990's, the plateauing and decline of $\mathrm{N}$ deposition allowed Fabaceae to recover. This may have contributed to the pattern of declines in long-tongued bumblebees, which were most severe during 1970-1989 and have become less accentuated since the 1990s (Carvalheiro et al. 2013). When closely associated food plants decline, the degree of impact to pollinators will depend on how severely the botanical trait is affected, whether the pollinator has a polylectic or oligolectic diet and if there are alternative food sources available, and whether oligolectic pollinators are able to show plasticity and adapt their foraging behaviour (Kleijn and Raemakers 2008).

Functional trait analysis of the botanical community can identify whether specific floral traits will increase or decrease in a community with $\mathrm{N}$ deposition. This, in turn, can be used to inform us which pollinator functional groups will be more affected by $\mathrm{N}$ deposition. Reduced overall functional diversity of the plant communities, and a decrease in entomophilous plants, have been found in European grassland communities and in floodplains in North Germany (Wesche et al. 2012; Helsen et al. 2014). Reduced floral diversity equates to reduced diversity of functional nectar and pollen traits, which can lead to impoverished species richness of bee assemblages (Potts et al. 2003, 2010; Fründ et al. 2010; Weiner et al. 2014). Stevens et al. (2018) performed a trait analysis on a dataset of acidic grasslands across the UK to give an insight into how the botanical degradation caused by $\mathrm{N}$ deposition and soil acidification might affect upland pollinator communities. The authors found that plants with floral structures suited to larger bees (e.g. bumblebees) and long-tongued pollinators, such as zygomorphic flowers or deep corollas, were more absent in areas that experienced higher levels of $\mathrm{N}$ deposition and with more acidic topsoil. The reduction of suitable forage plants within these habitats, caused by high levels of $\mathrm{N}$ deposition, can impose stress upon and threaten the associated functional groups of pollinators, such as long-tongued bumblebees. Generalist floral resources typically visited by smaller bee species were not negatively affected by $\mathrm{N}$ deposition or soil acidification. The results suggest that, in acidic grasslands, bees that visit generalist open flowers will not be as heavily impacted as specialist, long-tongued pollinators, and largebodied bees. The analysis also found that plants with lower nectar production are more prevalent in areas with higher levels of $\mathrm{N}$ deposition (Stevens et al. 2018), indicating that $\mathrm{N}$ deposition may reduce the overall quantity of nectar produced in upland acidic grasslands. 
Following the decline or termination of $\mathrm{N}$ application, botanical communities can remain in a state of low-diversity that reflects historic soil enrichment. Experiments have shown these conditions can persist for over 20 years following the cessation of $\mathrm{N}$ addition (Isbell et al. 2013). Although the overall community structure may be slow to recover, in some communities the occurrence of $\mathrm{N}$-sensitive species can increase within a couple of decades of declining $\mathrm{N}$ fluxes (Clark and Tilman 2008; Storkey et al. 2015). Evidence from the Park Grass Long-Term Experiment has shown that the decreasing levels of atmospheric $\mathrm{N}$ deposition since the 1990's has allowed a recent resurgence of Fabaceae and other important nectar and pollen resources (Storkey et al. 2015).

\section{Phenology}

Soil $\mathrm{N}$ content and additions can potentially alter the phenology of plants, but our understanding of how the flowering phenology of entomophilous plants responds across taxa is poor. Evidence from a field trial of experimental plots in coastal Central California found that addition of $\mathrm{N}$ to soils delayed flowering in grasses and slightly accelerated flowering of annual forbs (Cleland et al. 2006). This may be due to annual forbs increasing the partitioning of newly acquired nutrition to reproduction, whereas perennial grasses that can spread vegetatively might not partition so much energy towards floral units. In long-term experiments in UK, the ericaceous dwarf shrub Vaccinium myrtillus produced flower buds earlier with $\mathrm{N}$ additions $\left(20 \mathrm{~kg} \mathrm{~N} \mathrm{ha}^{-1}\right.$ year ${ }^{-1}$ in acidic grasslands, $60 \mathrm{~kg} \mathrm{~N} \mathrm{ha}^{-1}$ year $^{-1}$ in heathlands). Hoover et al. (2012) also found that $\mathrm{N}$ enrichment accelerated the flowering of Cucurbita maxima in a potted experiment. Other studies show that forbs can vary in their phenological response to increased soil $\mathrm{N}$ and do not always flower earlier. In a field experiment in a temperate steppe of North China, the flowering phenology of most forbs did not respond to the experimental addition of $100 \mathrm{~kg} \mathrm{~N} \mathrm{ha}^{-1}$ year $^{-1}$. However, Heteropappus altaicus had a delayed date of first flowering and Allium bidentatum had a shortened bloom duration (Xia and Wan 2013). In a Tibetan alpine meadow, the flowering phenology of three Ranunculaceae was monitored in response to $\mathrm{N}$ addition. Anemone trullifolia and Caltha scaposa responded; dates of first and last flowering were delayed. Trollius farreri showed no response (Liu et al. 2017). This is an example of inter-species variation of response within taxonomic families.

The Park Grass Long-Term Experiment at Rothamsted Research, has shown that chronic eutrophication can lead to local adaptation in flowering phenology (Silvertown et al. 2006). The field plots have received consistent $\mathrm{N}$ applications for over 150 years and populations of a grass species,
Anthoxanthum odoratum, flower at alternative times according to soil treatment, preventing pollen exchange between some populations (Snaydon and Davies 1982). This asynchrony between populations can theoretically lead to speciation. There has not yet been a similar study published that investigates the divergence of populations of entomophilous plants in Park Grass.

It is largely unknown how shifts in flowering phenology will influence pollinator communities (Miller-Rushing et al. 2010). Models predict that shifts in flowering phenology can disrupt interactions, potentially leading to network instability, reduced pollinator abundances, and potentially local extinctions (Memmott et al. 2007; Fabina et al. 2010). However, realistically, if species are able to adapt and find and utilise alternative food resources the impact should not be so severe (Benadi et al. 2014). Therefore, high plant species richness could buffer detrimental effects of phenological shifts, by providing alternative forage. The impact to pollinators will likely vary across ecosystems, depending on the plant and pollinator species present and on the extent of $\mathrm{N}$ enrichment. Unlike the effect of climatic warming, which can also accelerate insect emergence dates (Bartomeus et al. 2011; Ovaskainen et al. 2013), soil N enrichment will likely only affect plants, not their pollinators. Therefore, there is a potential for phenological asynchrony and of uncoupled specialised interactions, which can have negative implications for both pollinator communities and plant reproduction (Burkle et al. 2013; Kudo and Ida 2013).

\section{Floral production and morphology}

$\mathrm{N}$ addition has been shown to affect floral production; however, the responses are species-specific and often dependent on the amount of N. Several studies found that low additions of $\mathrm{N}$ to soils can enhance floral production, meaning more floral units per plant (Muñoz et al. 2005; Burkle and Irwin 2009a, b; Hoover et al. 2012). Increased floral production can drive an increase in pollinator visitation per plant (Muñoz et al. 2005; Burkle and Irwin 2010) and has been linked with improved insect pollinator diversity (Potts et al. 2010). In long-term experiments in UK heathlands, with $\mathrm{N}$ applications ranging between $7.7-60 \mathrm{~kg} \mathrm{~N} \mathrm{ha}^{-1}$ year $^{-1}$, flowering of the dominant shrub Calluna vulgaris increased with $\mathrm{N}$, with flowering at a maximum at the highest levels of $\mathrm{N}$ addition (Phoenix et al. 2012). In a subalpine meadow field experiment, Burkle and Irwin (2010) found that total floral production per plot, when including all species, was highest with low levels of $\mathrm{N}$ additions $\left(10 \mathrm{~kg} \mathrm{~N} \mathrm{ha}^{-1}\right.$ year $\left.^{-1}\right)$ compared to control or high $\mathrm{N}\left(200 \mathrm{~kg} \mathrm{~N} \mathrm{ha}^{-1}\right.$ year $\left.^{-1}\right)$ plots. These two studies indicate dose-dependent responses, but in contrasting ways. Dominant species may be more likely to maintain enhanced floral production with high $\mathrm{N}$ additions, 
as shown by Phoenix et al. (2012). On the other hand, for other species there is a narrow window of $\mathrm{N}$ addition in which enhanced floral production can benefit pollinators, but at higher levels floral production declines and positive effects diminish (Burkle and Irwin 2010). In the aforementioned subalpine study, the floral production of Potentilla pulcherrima decreased with high $\mathrm{N}$ addition $\left(200 \mathrm{~kg} \mathrm{~N} \mathrm{ha}^{-1}\right.$ year $^{-1}$ ) (Burkle and Irwin 2010). Declines in forb floral production were also observed in long-term UK grassland experiments (Phoenix et al. 2012). The authors noted how forb flowers declined more noticeably than forb cover, and may be a more sensitive indicator of responses to $\mathrm{N}$ deposition. As floral production is a more important metric than vegetation cover for pollinators, this is important to bear in mind when considering data on species composition. Gijbels et al. (2015) and Burkle and Irwin (2010) did not find any effect of $\mathrm{N}$ on floral production per plant in Gymnadenia conopsea and Ipomopsis aggregata, respectively. The range of responses of floral production to $\mathrm{N}$ addition shows that impacts to pollinators could vary across ecosystems, soil types, and botanical communities, as well as with levels of $\mathrm{N}$ addition.

Burkle and Irwin (2010) found that low N addition increased the length and width of corollas of Ipomopsis aggregata flowers. In many flowering plants with elongated corollas, the floral morphology has evolved to restrict access to unwanted visitors and selectively favour certain insects (Nilsson 1998). Significant changes to corolla morphology caused by $\mathrm{N}$ addition occur on much faster timescales than the co-evolved adaptations, and without the likewise adaptations of insect proboscises. Therefore, the elongation of corollas may exclude some of the preferred pollinators. Furthermore, if increased soil $\mathrm{N}$ causes corollas to widen, opportunistic and unwanted flower visitors may have better access to the valuable nectar supply. However, there is no evidence to determine whether alterations of floral dimensions or morphology will impact upon specialised pollinators or pollination services in the real world.

\section{Floral rewards: nectar}

Pollinating insects visit flowers to obtain the nutritional rewards that sustain them; nectar and pollen. Although pollen is digested by some adult insects and is required for the development of bee larvae, nectar is the most commonly sought reward and reason for visiting inflorescences. Nectar contains sugars and other compounds, such as amino acids, that are vital components of insect diets. It has been demonstrated that below-ground conditions affect nectar production and sugar content (Baude et al. 2011; Barber and Soper Gorden 2014). However, there are few studies exploring how nectar traits are affected by soil N. Our ability to understand how nectar traits are affected is confounded by the evidence of inter-specific response variation from these studies, thus making generalisations difficult.

In a study on the effects of nutrient additions to nectar traits, $\mathrm{N}$ addition did not increase the nectar secretion of Trifolium pratense, an $\mathrm{N}$-fixing Fabaceae, but it did increase secretion rate in Antirrhinum majus (Shuel 1956). In another study, nectar secretion increased in Ipomopsis aggregata but not in Linum lewisii or Potentilla pulcherrima (Burkle and Irwin 2009a, 2010). However, the increase in nectar secretion of A. majus and I. aggregata was only observed at low levels of $\mathrm{N}$ addition ( $10 \mathrm{~kg} \mathrm{~N} \mathrm{ha}^{-1}$ year $^{-1}$ for I. aggregata). At high levels of $\mathrm{N}$ addition $\left(200 \mathrm{~kg} \mathrm{~N} \mathrm{ha}^{-1}\right.$ year $^{-1}$ for I. aggregata), nectar secretion decreased for both species (Shuel 1956; Burkle and Irwin 2010). This suggests that while low $\mathrm{N}$ deposition might bring benefits for nectarfeeding insects, excessively high deposition will not.

The composition of sugars within nectar is an important determinant of insect visitation and niche division. A more diverse selection of nectar sugar compositions can improve the richness of pollinator assemblages (Potts et al. 2003), due to the preferences and requirements of different pollinator guilds. For instance, Hymenoptera pollinators prefer high sucrose nectars, Diptera visit lower sucrose nectars, and Lepidopteran flower visitors are intermediate (Petanidou 2005). Some species show sex-specific nectar niches; Rusterholtz and Erhardt (2000) found that females of Lysandra bellargus, a threatened European Lepidoptera, preferred high glucose nectars whereas males preferred high sucrose. Ceulemans et al. (2017), studying Succisa pratensis, demonstrated that the composition of sugars can be affected by soil nutrient enrichment with $\mathrm{N}$ and phosphorous (P); glucose proportionally decreased. Whether this response is uniform across more species is unknown; S. pratensis is an N-sensitive species (Hill 1999) and there may be interspecific response variation. It is possible that alterations to the composition of sugars in nectar can impact on the diets of particular pollinator guilds and disrupt the interaction niches. Whether the alteration of nectar sugar composition is enough to influence plant-pollinator networks is unknown and requires further research.

Floral nectars contain many other compounds, in addition to sugars, that can directly impact the nutritional qualities and attractiveness of nectar (Alm et al. 1990; Carter and Thornburg 2004; González-Teuber and Heil 2009; Nepi et al. 2012; Nepi 2014). Amino acids are found ubiquitously in nectar (Baker 1977), and are a necessary component of insect diets. The amino acid content of nectar can be a driver of bee health and mortality; Paoli et al. (2014) found high amino acid diets increased the lifespan of queen-right Apis mellifera workers, but decreased the lifespan of queenless workers. Excessively high levels of amino acids may be problematic or even dangerous for 
pollinating insects, for example naturally high concentrations of the non-protein amino acid $\beta$-alanine in the nectar of Gentiana lutea have been observed to stun and reduce motor skills in foraging bees (Nepi 2014).

High soil $\mathrm{N}$ content, and $\mathrm{N}$ additions, have been shown to increase total amino acid content in most studies (Gardener and Gillman 2001; Gijbels et al. 2014, 2015), with Gardener and Gillman (2001) observing a linear relationship between $\mathrm{N}$ addition and nectar amino acid content. Of the individual amino acids, asparagine and glutamine are commonly observed to increase with $\mathrm{N}$ addition (Gardener and Gillman 2001; Gijbels et al. 2015; Ceulemans et al. 2017). Where levels of soil $\mathrm{N}$ are excessive, glutamine can be excreted from some plant species to avoid cellular damage, which could explain the increased proportion of glutamine in the nectar of fertilised plants (Gardener and Gillman 2001; Gijbels et al. 2015). Other amino acids observed to increase with soil $\mathrm{N}$ addition in individual studies are serine in Gymnadenia conopsea, a Lepidoptera-pollinated Orchidaceae (Gijbels et al. 2014), and proline in Agrostemma githago (Gardener and Gillman 2001). There are no common trends in the amino acids that decrease in production; rather the responses are specific to individual experiments and study species. Gijbels et al. (2015) observed a decrease in arginine, aspartic acid, and glutamic acid in the nectar of Gymnadenia conopsea. These three amino acids inhibit the chemosensory cells of Diptera (Shiraishi and Kuwabara 1970). Although G. conopsea is Lepidoptera-pollinated, if this response is found in other plants it could affect the taste perception and foraging choices of Dipteran pollinators, such as Syrphideae (Gijbels et al. 2015). Gamma-aminobutyric acid (GABA), proline, and glutamine share a common biosynthetic pathway from glutamine alpha-ketoglutarate. In a study on the effects of $\mathrm{N}$ addition to the nectar amino acid profile of Agrostemma githago, Gardener and Gillman (2001) observed a decrease in GABA alongside an increase in proline and glutamine. This suggests a potential response mechanism whereby proline and glutamine are present at higher concentrations at the expense of GABA (Gardener and Gillman 2001). GABA, and its close association with $\mathrm{NaCl}$ salt, has phagostimulatory effects on insects but can be dangerous for larvae at high concentrations (Nepi 2014). Therefore, it is not clear whether a decrease in GABA would affect pollinators positively or negatively. The increase in proline concentration could be useful for pollinators; it is rapidly metabolised and is useful for the conversion of energy in initialising flight in invertebrates (Carter et al. 2006). It also serves as an attractant; Bertazzini et al. (2010) found honeybees were more attracted to proline than serine, alanine, or control solutions. However, its attractiveness is highest at moderate levels, with bees becoming less interested at higher concentrations (Carter et al. 2006).

As with sugars, amino acids in nectar are shown to be correlated with certain functional groups of pollinators. Petanidou et al. (2006), studying a Mediterranean plant community of 73 species, found pollinator preference was the strongest determinant of nectar amino acid composition, more so than life-history or taxonomic group. This is highly suggestive of an ecological role of nectar amino acids that influence plant-pollinator networks. For example, phenylalanine and $\gamma$-aminobutyric acid (GABA) are found in high concentrations in plants pollinated by bumblebees and long-tongued solitary bees (Petanidou et al. 2006; Nepi 2014). Petanidou et al. (2006) also observed that total amino acid content was correlated with the number of long-tongued visitors. Sex-specific niches also exist with regards to amino acids; females of the threatened Lysandra bellargus butterfly prefer a diet high in amino acids (Rusterholtz and Erhardt 2000), potentially to enhance fecundity (Mevi-Schütz and Erhardt 2005). The variation in nectar preferences and niches across insect pollinator taxa suggests an important role for nectar chemistry in the diets of insects. However, it is not known if the changes to nectar brought about by $\mathrm{N}$ deposition will impact on plant-pollinator interactions.

We are lacking evidence of how soil $\mathrm{N}$ affects the production of defensive secondary compounds in floral nectar (González-Teuber and Heil 2009). Alkaloids, glycosides, and phenolics play a role in selectively limiting flower visitors (Carter and Thornburg 2004; Nepi 2014). At low levels these substances can be important for the health of pollinating bees, by reducing parasite loads (Richardson et al. 2015, 2016). However, in excessively high concentrations alkaloids are repellent and can reduce mobility and motor function of bees (Manson et al. 2013). The addition of $\mathrm{N}$ can increase the production of natural defensive compounds in vegetation (Chen et al. 2010); if a similar response is found in floral nectar there may be consequences for pollinating insects. There has also been no research into how floral volatiles, which are used by bees during early foraging trips to identify sources of nectar and pollen (Dötterl and Vereecken 2010), are affected by soil N. Without a broad understanding that encompasses the less prevalent components of nectar, it is difficult to forecast how nectar traits affected by soil $\mathrm{N}$ will impact pollinators.

Although there are few studies into how soil $\mathrm{N}$ affects nectar traits, research that includes the impact on pollinators is even sparser. Ceulemans et al. (2017) housed colonies of Bombus terrestris with Succisa pratensis, to investigate the effects of nutrient enrichment on floral reward chemistry and colony development. The study found that colonies housed with enriched Succisa pratensis had more dead and ejected larvae from Bombus terrestris colonies, leading to a smaller colony with fewer workers during the colony's mid-life. The 
study did not identify whether a specific component of nectar or pollen was the cause, but it is evidence that high soil enrichment may be detrimental to colony health. Hoover et al. (2012) artificially made Cucurbita maxima nectar from a 'recipe' of sugars and amino acids that represented the concentrations found in control and $\mathrm{N}$-enriched plants. In this experiment, Bombus terrestris workers preferentially visited and consumed nectar of enriched plants, but their lifespan decreased. These two studies reveal negative impacts of soil $\mathrm{N}$ enrichment on the development and longevity of a key pollinating species, which could potentially lead to impoverished pollinator populations and pollination services. However, it should be noted that the artificial nectar used by Hoover et al. (2012) only contained sugars and amino acids, without the less prevalent secondary compounds, so is not necessarily applicable to real-world responses. Evidence on other key pollinating species, such as wild solitary bees, would be useful to ascertain the occurrence of this response.

\section{Floral rewards: pollen}

Many flower visitors feed on or collect pollen, including agricultural pests (such as the pollen beetle) and important pollinators. Bees collect pollen to rear their young, and the botanical origin, quantity, and chemistry of pollen can affect the health and mortality of future generations of these key pollinators (Roulston et al. 2000; Potts et al. 2003; Sedivy et al. 2011; Vanderplanck et al. 2014). Foraging bees are able to recognise and preferentially forage pollen that has a higher content of essential amino acids (Cook et al. 2003). Pollen with higher protein and amino acid content lead to more and larger larvae (Génissel et al. 2002; Vanderplanck et al. 2014) and without sufficient amounts of key amino acids, larvae are unable to develop and survive (Roulston and Cane 2000). Therefore, the nutritional qualities of pollen are important for ensuring sustainable pollinator communities.

Ceulemans et al. (2017) found soil enrichment with $\mathrm{N}$ and $\mathrm{P}$ altered the sugar composition of Succisa pratensis pollen; glucose increased and fructose decreased. The authors also recorded a shift in the amino acid profile, with asparagine and ornithine increasing alongside a decrease in arginine, glycine, and threonine. However, as the content of proteins, amino acids, and other compounds in pollen varies across botanical species (Szczesna 2006), there is likely inter-species variation in the response to increasing soil $\mathrm{N}$. As noted previously, Ceulemans et al. (2017) found that floral rewards from nutrient-enriched plants caused more dead and ejected larvae from Bombus terrestris colonies, although the study did not establish if this response was due to changes in nectar or pollen qualities.
Burkle and Irwin (2010) did not find any change to the production of pollen per individual flower with $\mathrm{N}$ addition. However, the increase in floral production of Ipomopsis aggregata with low $\mathrm{N}$ addition $\left(10 \mathrm{~kg} \mathrm{~N} \mathrm{ha}^{-1}\right.$ year $\left.^{-1}\right)$ resulted in greater overall pollen production per plant. On the other hand, with high $\mathrm{N}$ addition $\left(200 \mathrm{~kg} \mathrm{~N} \mathrm{ha}^{-1}\right.$ year $\left.{ }^{-1}\right)$, Potentilla pulcherrima floral production decreased, causing an overall decrease in pollen production per plant. Lau and Stephenson (1993) found that Cucurbita pepo pollen grains from high $\mathrm{N}$ soils were $5 \%$ larger; however, whether this translates to higher overall nutritional content was not explored.

Bees develop dietary niches with pollen specialisms more often than nectar specialisms, due to the importance of pollen in rearing offspring. These are driven by secondary metabolites found in low concentrations in pollen, and closely related bee species can differ in their tolerances of some pollen compounds (Sedivy et al. 2011). There is not yet any research into how soil $\mathrm{N}$ affects the defensive compounds of pollen; if so, this could create stress and mortality for the larvae of some pollen specialists.

\section{Knowledge gaps}

\section{The impact to pollinators}

While there is some research that investigates how $\mathrm{N}$ additions affect the discussed botanical traits, we have very few studies concerning the actual impacts to pollinators. This is a key knowledge gap; the lack of causative research into how botanical traits affected by soil $\mathrm{N}$ consequentially affect pollinators. With $\mathrm{N}$ deposition set to rise in many parts of the globe in the future, it is important to know how pollinators will respond to background additions of $\mathrm{N}$. Without research that incorporates pollinators into the experimental set-up it is impossible to know if, and how strongly, plant-pollinator interactions will be affected. It is important to know how the developmental and reproductive fitness of pollinators are affected by atmospheric $\mathrm{N}$ deposition or the addition of fertilisers. We also need to ascertain if responses are consistent across botanical and insect taxa, or if some interactions and functional groups are more threatened than others. Finally, there is also evidence that low additions of $\mathrm{N}$ can lead to changes in floral traits that may benefit pollinators, whereas the effects at higher rates of addition can be adverse (Muñoz et al. 2005; Burkle and Irwin 2009a, b; Burkle and Irwin 2010; Hoover et al. 2012). Clarity is required as to the thresholds beyond which $\mathrm{N}$ addition becomes detrimental for pollinators in various habitats.

Many studies use generalist pollinators, such as Apis mellifera, as a study species. It is important to consider the wider pollinator community, as some specialist pollinator 
functional groups or species may be more threatened by $\mathrm{N}$ deposition. WallisDeVries and van Swaay (2017) developed an $\mathrm{N}$ index for butterflies based on host plants, which illustrates the species that have been most impacted by $\mathrm{N}$ deposition and soil eutrophication. It may be possible to develop similar indices to help forecast the effect of atmospheric $\mathrm{N}$ deposition on other pollinators. There are oligolectic bee species with narrow diet breadths, such as Chelostoma sp. (Sedivy et al. 2008; Denisow and Wrzesień 2015), and longtongued bumblebees with identifiable key forage plants. However, most bee species forage relatively opportunistically, which complicates the development of an N-sensitivity index encompassing all bee species. Given the inconsistency of responses to increasing soil $\mathrm{N}$ between plant species across the range of processes discussed above, it is likely that whether $\mathrm{N}$ additions lead to a net positive or negative response of pollinators will be dependent on specific plant/ invertebrate assemblages. Developing a predictive framework will, therefore, require network analyses of plant-pollinator interactions along a soil fertility gradient as opposed to correlative models of total pollinator abundance or diversity.

\section{Inter-specific variation and the synthesis of botanical traits}

Research into how soil $\mathrm{N}$ affects relevant botanical traits, including flowering phenology and, especially, nectar and pollen chemistry are lacking (Nijssen et al. 2017), making it difficult to understand the impacts of $\mathrm{N}$ additions to pollinators. This task is further confounded by the inter-species variation found for these traits, evidenced through the studies to date. Many experiments so far have used individual study species, and therefore we lack enough data to be able to understand the mechanistic reasons for these species-specific responses. Further field studies incorporating a range of botanical taxa can help to address this knowledge gap. Life-history traits of plants, such as annuality and perenniality, or $\mathrm{N}$-preferences as denoted by Ellenberg $\mathrm{N}$ values (Hill 1999), may offer a predictive tool for the responses of botanical traits (Burkle and Irwin 2009a). Developing our understanding of inter-specific response variation will enhance our ability to forecast how ecosystems will respond to $\mathrm{N}$ addition.

To understand the overall impact of soil $\mathrm{N}$ on pollinator communities, we need to synthesise our understanding of the various botanical traits. This will improve the real-world applicability of research. For example, increased floral production and nectar secretion are beneficial responses for pollinators, but this may be completely negated, and the overall response detrimental, if the botanical species declines, if flowering phenology is dramatically shifted, or if production of toxic defensive compounds becomes excessive. When possible, future research should focus on a suite of botanical traits to more accurately determine the overall impact to insect pollinators.

If we combine this with an improved understanding of inter-specific variation, we can synthesise knowledge of various botanical traits and botanical taxa. We can then more accurately forecast how $\mathrm{N}$ addition alters plant communities for prospective pollinating insects. It would be useful to incorporate knowledge of nectar and pollen chemistry into our understanding of the compositional changes in botanical species, to reflect the actual changes of nutritional resources in an affected plant community. For example, Taraxacum officinale agg. is $\mathrm{N}$-tolerant and is popularly visited by insects for nectar and pollen. However, an increase in $T$. officinale at the expense of other flowering plants is not necessarily beneficial; its pollen is lacking in key amino acids and bee larvae cannot survive on it alone (Roulston and Cane 2000; Génissel et al. 2002). By understanding the responses of plants to $\mathrm{N}$ addition across taxa and traits, and synthesising this knowledge, we can more accurately understand the impact to pollinators.

\section{Biotic interactions}

A key impact of atmospheric $\mathrm{N}$ deposition or the addition of fertilisers is the changing dynamics of botanical competition for increased nutritional resources. The interactions of plants as they compete for resources can also be a factor that affects floral and nectar traits (Baude et al. 2011). Therefore, field studies, or at least potted experiments that are representative of realistic botanical communities, will more reliably depict how plants respond to $\mathrm{N}$ addition. Studies of individual species might help to address general knowledge gaps in the subject, but we cannot be certain of the real-world applicability of these results without incorporating the effect of plant competition dynamics.

Soil biota and herbivores are affected by $\mathrm{N}$ deposition and impacts to these groups may have effects on pollinators. Below-ground biota and processes affect floral traits, and can alter pollinator visitation in a variety of ways (Scheu 2001; Barber and Soper Gorden 2014). Again, the responses of nectar and pollen chemistry are understudied; Barber and Soper Gordon (2014) note that little research has investigated the effect of soil biota on the nutritional value of floral rewards. Herbivory, which can be influenced by soil $\mathrm{N}$ (Phoenix et al. 2012), can also affect pollination, generally by reducing the attractiveness of plants (A'Bear et al. 2014). The effects of atmospheric $\mathrm{N}$ deposition on ecosystems are complex, involving indirect interactions amongst trophic and functional groups of organisms. Therefore, synthesis of research into how $\mathrm{N}$ affects rhizosphere, plants, and herbivory would better inform our understanding of how $\mathrm{N}$ deposition affects pollinators. 


\section{Abiotic interactions}

Future environmental scenarios will involve a complex system of multiple drivers. Studies have shown that aspects of climate change can act interactively with fertiliser use strategies, with the strength and direction of the interaction varying between studies (de Chazal and Rounsevell 2009). Atmospheric $\mathrm{N}$ deposition is only a single driver of global environmental change and will not necessarily act alone (Tylianakis et al. 2008; Burkle and Alarcon 2011; González-Varo et al. 2013). Realistically, an ecosystem will experience $\mathrm{N}$ deposition alongside increased atmospheric $\mathrm{CO}_{2}$ and a changing climate. Evidence shows these drivers can act interactively to alter botanical traits differently than when acting individually (Cleland et al. 2006; Tylianakis et al. 2008; Hoover et al. 2012). For example, although climate warming is known to accelerate flowering phenology of many plant species (Fitter et al. 1995; Thórhallsdóttir 1998; Miller-Rushing and Primack 2008), the response can also be affected by soil $\mathrm{N}$ (Cleland et al. 2006, Hoover et al. 2012). Excessive soil N enrichment can exacerbate the stress plants experience from climatic events such as draughts and severe frost (Phoenix et al. 2012). If these events increase in frequency with future climate change, plants may suffer further.

Our knowledge of the impacts of $\mathrm{N}$ deposition on pollinators is patchy. While studies that consider the effects of $\mathrm{N}$ are important and required, we should consider that botanical responses can be intensified or dampened by other drivers of environmental change. Research that addresses the combined effect of these drivers of environmental change are necessary to more clearly understand how pollinator communities will be affected in the future.

Acknowledgements T.I.D. is funded by the Lawes Agricultural Trust. J.S. is supported by research programme NE/N018125/1 LTS-M ASSIST-Achieving Sustainable Agricultural Systems, funded by the National Environment Research Council and the Biotechnology and Biosciences Research Council.

Open Access This article is distributed under the terms of the Creative Commons Attribution 4.0 International License (http://creativeco mmons.org/licenses/by/4.0/), which permits unrestricted use, distribution, and reproduction in any medium, provided you give appropriate credit to the original author(s) and the source, provide a link to the Creative Commons license, and indicate if changes were made.

\section{References}

A'Bear DA, Johnson SN, Jones HT (2014) Putting the 'upstairs-downstairs' into ecosystem service: what can aboveground-belowground ecology tell us? Biol Control 75:97-107. https://doi. org/10.1016/j.biocontrol.2013.10.004
Alm J, Ohnmeiss TE, Lanza J, Vriesenga L (1990) Preference of cabbage white butterflies and honey bees for nectar that contains amino acids. Oecologia 84:53-57. https://doi.org/10.1007/BF006 65594

Aqueel MA, Leather SR (2012) Nitrogen fertiliser affects the functional response and prey consumption of Harmonia axyridis (Coleoptera: Coccinellidae) feeding on cereal aphids. Ann Appl Biol 160:6-15. https://doi.org/10.1111/j.1744-7348.2011.00514.x

Baker HG (1977) Non-sugar chemical constituents of nectar. Apidologie 8:349-356

Banfield-Zanin JA, Rossiter JT, Wright DJ et al (2012) Predator mortality depends on whether its prey feeds on organic or conventionally fertilised plants. Biol Control 63:56-61. https://doi. org/10.1016/j.biocontrol.2012.05.008

Barber NA, Soper Gorden NL (2014) How do belowground organisms influence plant-pollinator interactions? J Plant Ecol 8:1-11. https://doi.org/10.1093/jpe/rtu012

Bartomeus I, Vilà M, Santamaría L (2008) Contrasting effects of invasive plants in plant-pollinator networks. Oecologia 155:761-770. https://doi.org/10.1007/s00442-007-0946-1

Bartomeus I, Ascher JS, Wagner D et al (2011) Climate-associated phenological advances in bee pollinators and bee-pollinated plants. Proc Natl Acad Sci USA 108:20645-20649. https://doi. org/10.1073/pnas.1115559108

Baude M, Leloup J, Suchail S et al (2011) Litter inputs and plant interactions affect nectar sugar content. J Ecol 99:828-837. https://doi.org/10.1111/j.1365-2745.2011.01793.x

Baude M, Kunin WE, Boatman ND et al (2016) Historical nectar assessment reveals the fall and rise of floral resources in Britain. Nature 530:85-88. https://doi.org/10.1038/nature16532

Benadi G, Hovestadt T, Poethke HJ, Blüthgen N (2014) Specialization and phenological synchrony of plant-pollinator interactions along an altitudinal gradient. J Anim Ecol 83:639-650. https://doi.org/10.1111/1365-2656.12158

Bertazzini M, Medrzycki P, Bortolotti L et al (2010) Amino acid content and nectar choice by forager honeybees (Apis mellifera L.). Amino Acids 39:315-318. https://doi.org/10.1007/s0072 6-010-0474-x

Biesmeijer JC, Roberts SPM, Reemer M et al (2006) Parallel declines in pollinators and insect-pollinated plants in Britain and the Netherlands. Science 313:351-354. https://doi.org/10.1126/ science. 1127863

Bleeker A, Hicks WK, Dentener F et al (2011) Nitrogen deposition as a threat to the world's protected areas under the convention on biological diversity (CBD). Environ Pollut 159:295-303. https://doi.org/10.1007/978-94-007-7939-6_31

Bobbink R, Hornung M, Roelofs JGM (1998) The effects of airborne nitrogen pollutants on species diversity in natural and semi-natural European vegetation. J Ecol 86:717-738. https:// doi.org/10.1046/j.1365-2745.1998.8650717.x

Bobbink RB, Hicks KH, Galloway JG et al (2010) Global assessment of nitrogen deposition effects on terrestrial plant diversity: a synthesis. Ecol Appl 20:30-59

Brunsting AAMH, Heil GW (1985) The role of nutrients in the interactions between a herbivorous beetle and some competing plant species in heathlands. Nord Soc Oikos 44:23-26

Burkle LA, Alarcon R (2011) The future of plant-pollinator diversity: understanding interaction networks across time, space, and global change. Am J Bot 98:528-538. https://doi. org/10.3732/ajb.1000391

Burkle L, Irwin R (2009a) The importance of interannual variation and bottom-up nitrogen enrichment for plant-pollinator networks. Oikos 118:1816-1829. https://doi.org/10.111 1/j.1600-0706.2009.17740.x

Burkle LA, Irwin RE (2009b) The effects of nutrient addition on floral characters and pollination in two subalpine plants, 
Ipomopsis aggregata and Linum lewisii. Plant Ecol 203:83-98. https://doi.org/10.1007/s11258-008-9512-0

Burkle LA, Irwin RE (2010) Beyond biomass: measuring the effects of community-level nitrogen enrichment on floral traits, pollinator visitation and plant reproduction. J Ecol 98:705-717. https://doi.org/10.1111/j.1365-2745.2010.01648.x

Burkle LA, Marlin JC, Knight TM (2013) plant-pollinator interactions over 120 years: loss of species, co-occurrence, and function. Science 339:1611-1616

Caporn SJM, Ashenden TW, Lee JA (2000) The effect of exposure to $\mathrm{NO}_{2}$ and $\mathrm{SO}_{2}$ on frost hardiness in Calluna vulgaris. Environ Exp Bot 43:111-119. https://doi.org/10.1016/S0098 -8472(99)00050-7

Carter C, Thornburg RW (2004) Is the nectar redox cycle a floral defense against microbial attack? Trends Plant Sci 9:320-324. https://doi.org/10.1016/j.tplants.2004.05.008

Carter C, Shafir S, Yehonatan L et al (2006) A novel role for proline in plant floral nectars. Naturwissenschaften 93:72-79. https:// doi.org/10.1007/s00114-005-0062-1

Carvalheiro LG, Kunin WE, Keil P et al (2013) Species richness declines and biotic homogenisation have slowed down for NWEuropean pollinators and plants. Ecol Lett 16:870-878. https ://doi.org/10.1111/ele.12121

Ceulemans T, Hulsmans E, Vanden Ende W, Honnay O (2017) Nutrient enrichment is associated with altered nectar and pollen chemical composition in Succisa pratensis Moench and increased larval mortality of its pollinator Bombus terrestris L. PLoS ONE 12:1-15. https://doi.org/10.1371/journ al.pone. 0175160

Chen Y, Olson DM, Ruberson JR (2010) Effects of nitrogen fertilization on tritrophic interactions. Arthropod Plant Interact 4:81-94. https://doi.org/10.1007/s11829-010-9092-5

Clark CM, Tilman D (2008) Loss of plant species after chronic low-level nitrogen deposition to prairie grasslands. Nature 451:712-715. https://doi.org/10.1038/nature06503

Clark CM, Cleland EE, Collins SL et al (2007) Environmental and plant community determinants of species loss following nitrogen enrichment. Ecol Lett 10:596-607. https://doi.org/10.111 1/j.1461-0248.2007.01053.x

Cleland EE, Chiariello NR, Loarie SR et al (2006) Diverse responses of phenology to global changes in a grassland ecosystem. Proc Natl Acad Sci USA 103:13740-13744. https://doi.org/10.1073/ pnas.0600815103

Cook SM, Awmack CS, Murray D, Williams IH (2003) Are honey bees' foraging preferences affected by pollen amino acid composition? Ecol Entomol 28:622-627. https://doi.org/10.104 6/j.1365-2311.2003.00548.x

Cornell SE, Jickells TD, Cape JN et al (2003) Organic nitrogen deposition on land and coastal environments: a review of methods and data. Atmos Environ 37:2173-2191. https://doi. org/10.1016/S1352-2310(03)00133-X

Crawley MJ, Johnston AE, Silvertown J et al (2005) Determinants of species richness in the Park Grass Experiment. Am Nat 165:179-192. https://doi.org/10.1086/427270

de Chazal J, Rounsevell MDA (2009) Land-use and climate change within assessments of biodiversity change: a review. Glob Environ Chang 19:306-315. https://doi.org/10.1016/j.gloen vcha.2008.09.007

Denisow B, Wrzesien M (2015) The habitat effect on the diversity of pollen resources in several Campanula spp.-an implication for pollinator conservation. J Apic Res 54:62-71. https://doi. org/10.1080/00218839.2015.1030243

Dentener F, Drevet J, Lamarque JF et al (2006) Nitrogen and sulfur deposition on regional and global scales: a multimodel evaluation. Glob Biogeochem Cycles. https://doi.org/10.1029/2005G B002672
Diekmann M, Jandt U, Alard D et al (2014) Long-term changes in calcareous grassland vegetation in North-western Germanyno decline in species richness, but a shift in species composition. Biol Conserv 172:170-179. https://doi.org/10.1016/j. biocon.2014.02.038

Dötterl S, Vereecken NJ (2010) The chemical ecology and evolution of bee-flower interactions: a review and perspectives. Can J Zool 88:668-697. https://doi.org/10.1139/Z10-031

Duprè C, Stevens CJ, Ranke T et al (2010) Changes in species richness and composition in European acidic grasslands over the past 70 years: the contribution of cumulative atmospheric nitrogen deposition. Glob Chang Biol 16:344-357. https://doi.org/10.11 $11 /$ j.1365-2486.2009.01982.x

Erisman JW, Galloway JN, Seitzinger S et al (2014) Consequences of human modification of the global nitrogen cycle. Phil Trans R Soc B 368:1-9. https://doi.org/10.1098/rstb.2013.0116

Fabina NS, Abbott KC, Gilman RT (2010) Sensitivity of plant-pollinator-herbivore communities to changes in phenology. Ecol Model 221:453-458. https://doi.org/10.1016/j.ecolmodel.2009.10.020

Farrer EC, Suding KN (2016) Teasing apart plant community responses to $\mathrm{N}$ enrichment: the roles of resource limitation, competition and soil microbes. Ecol Lett 19:1287-1296. https://doi.org/10.1111/ ele. 12665

Field CD, Dise NB, Payne RJ et al (2014) The role of nitrogen deposition in widespread plant community change across semi-natural habitats. Ecosystems 17:864-877. https://doi.org/10.1007/s1002 1-014-9765-5

Fitter A, Fitter R, Harris I, Williamson M (1995) Relationships between first flowering date and temperature in the flora of a locality in Central England. Funct Ecol 9:55-60

Fontaine C, Dajoz I, Meriguet J, Loreau M (2006) Functional diversity of plant-pollinator interaction webs enhances the persistence of plant communities. PLoS Biol 4:0129-0135. https:// doi.org/10.1371/journal.pbio.0040001

Fowler D, O'Donoghue M, Muller JB et al (2004) A chronology of nitrogen deposition in the UK between 1900 and 2000. Water Air Soil Pollut 4:9-23. https://doi.org/10.1007/s11267-004-3009-1

Fowler D, Coyle M, Skiba U et al (2013) The global nitrogen cycle in the twenty-first century. Philos Trans R Soc B 368:1-13. https:// doi.org/10.1098/rstb.2013.0164

Fründ J, Linsenmair KE, Blüthgen N (2010) Pollinator diversity and specialization in relation to flower diversity. Oikos 119:15811590. https://doi.org/10.1111/j.1600-0706.2010.18450.x

Fründ J, Dormann CF, Holzschuh A, Tscharntke T (2013) Bee diversity effects on pollination depend on functional complementarity and niche shifts. Ecology 94:2042-2054. https://doi. org/10.1890/12-1620.1

Gallai N, Salles J, Settele J, Vaissière BE (2008) Economic valuation of the vulnerability of world agriculture confronted with pollinator decline. Ecol Econ 68:810-821. https://doi.org/10.1016/j.ecole con.2008.06.014

Galloway JN, Dentener FJ, Capone DG et al (2004) Nitrogen cycles: past, present, and future. Biogeochemistry 70:153-226. https:// doi.org/10.1007/s 10533-004-0370-0

Galloway JN, Trends R, Townsend AR et al (2008) Transformation of the nitrogen cycle: potential solutions. Science 320:889-892. https://doi.org/10.1126/science.1136674

Gardener MC, Gillman MP (2001) The effects of soil fertilizer on amino acids in the floral nectar of corncockle, Agrostemma githago (Caryophyllaceae). Oikos 92:101-106. https://doi.org/ 10.1034/j.1600-0706.2001.920112.x

Garibaldi LA, Aizen MA, Klein AM et al (2011) Global growth and stability of agricultural yield decrease with pollinator dependence. Proc Natl Acad Sci USA 108:5909-5914. https://doi. org/10.1073/pnas.1012431108 
Garibaldi LA, Steffan-dewenter I, Winfree R et al (2014) Wild pollinators enhance fruit set of crops regardless of honey bee abundance. Science 339:1608-1611. https://doi.org/10.1098/rspb.2006.3721

Génissel A, Aupinel P, Bressac C et al (2002) Influence of pollen origin on performance of Bombus terrestris micro-colonies. Entomol Exp Appl 104:329-336. https://doi.org/10.1023/A:1021279220 995

Gijbels P, Van den Ende W, Honnay O (2014) Landscape scale variation in nectar amino acid and sugar composition in a Lepidoptera pollinated orchid species and its relation with fruit set. J Ecol 102:136-144. https://doi.org/10.1111/1365-2745.12183

Gijbels P, Ceulemans T, Van den Ende W, Honnay O (2015) Experimental fertilization increases amino acid content in floral nectar, fruit set and degree of selfing in the orchid Gymnadenia conopsea. Oecologia 179:785-795. https://doi.org/10.1007/s0044 2-015-3381-8

González-Teuber M, Heil M (2009) Nectar chemistry is tailored for both attraction of mutualists and protection from exploiters. Plant Signal Behav 4:809-813. https://doi.org/10.4161/psb.4.9.9393

González-Varo JP, Biesmeijer JC, Bommarco R et al (2013) Combined effects of global change pressures on animal-mediated pollination. Trends Ecol Evol 28:524-530. https://doi.org/10.1016/j. tree.2013.05.008

Goulding KWT, Bailey NJ, Bradbury NJ et al (2015) Nitrogen deposition and its contribution to nitrogen cycling and associate soil processes. New Phytol 139:49-58

Haddad NM, Haarstad J, Tilman D (2000) The effects of long-term nitrogen loading on grassland insect communities. Oecologia 124:73-84. https://doi.org/10.1007/s004420050026

Harrison T, Winfree R (2015) Urban drivers of plant-pollinator interactions. Funct Ecol 29:879-888. https://doi. org/10.1111/1365-2435.12486

Helsen K, Ceulemans T, Stevens CJ, Honnay O (2014) Increasing soil nutrient loads of european semi-natural grasslands strongly alter plant functional diversity independently of species loss. Ecosystems 17:169-181. https://doi.org/10.1007/s10021-013-9714-8

Hill MO (1999) Ellenberg's indicator values for British plants. ECOFACT-Technical Annex, vol 47. Grange-over-Sands, Cumbria. https://doi.org/10.1017/CBO9781107415324.004

Hoover SER, Ladley JJ, Shchepetkina AA et al (2012) Warming, $\mathrm{CO}_{2}$, and nitrogen deposition interactively affect a plant-pollinator mutualism. Ecol Lett 15:227-234. https://doi.org/10.111 1/j.1461-0248.2011.01729.x

Humbert JY, Dwyer JM, Andrey A, Arlettaz R (2016) Impacts of nitrogen addition on plant biodiversity in mountain grasslands depend on dose, application duration and climate: a systematic review. Glob Chang Biol 22:110-120

Isbell F, Tilman D, Polasky S et al (2013) Low biodiversity state persists two decades after cessation of nutrient enrichment. Ecol Lett 16:454-460. https://doi.org/10.1111/ele.12066

Jefferies RL, Maron JL (1997) The embarassment of riches: atmospheric deposition of nitrogen and community and ecosystem processes. Trends Ecol Evol 12:74-77

Kleijn D, Raemakers I (2008) A retrospective analysis of pollen host plant use by stable and declining bumble bee species. Ecology 89:1811-1823. https://doi.org/10.1890/07-1275.1

Klein AM, Vaissiere BE, Cane JH, Steffan-Dewenter I, Cunningham SA, Kremen C, Tscharntke T (2007) Importance of pollinators in changing landscapes for world crops. Proc R Soc B 274:303-313. https://doi.org/10.1098/rspb.2006.3721

Kudo G, Ida TY (2013) Early onset of spring increases the phenological mismatch between plants and pollinators. Ecology 94:23112320. https://doi.org/10.1890/12-2003.1

Lau TC, Stephenson AG (1993) Effects of soil nitrogen on pollen production, pollen grain size, and pollen performance in Cucurbita pepo (Cucurbitaceae). Am J Bot 80:763-768. https://doi. org/10.1002/j.1537-2197.1993.tb15292.x

Liu X, Zhang Y, Han W et al (2013) Enhanced nitrogen deposition over China. Nature 494:459-462. https://doi.org/10.1038/nature11917

Liu Y, Miao R, Chen A et al (2017) Effects of nitrogen addition and mowing on reproductive phenology of three early-flowering forb species in a Tibetan alpine meadow. Ecol Eng 99:119125. https://doi.org/10.1016/j.ecoleng.2016.11.033

Lopezaraiza-Mikel ME, Hayes RB, Whalley MR, Memmott J (2007) The impact of an alien plant on a native plant-pollinator network: an experimental approach. Ecol Lett 10:539-550. https ://doi.org/10.1111/j.1461-0248.2007.01055.x

Manson JS, Cook D, Gardner DR, Irwin RE (2013) Dose-dependent effects of nectar alkaloids in a montane plant-pollinator community. J Ecol 101:1604-1612. https://doi. org/10.1111/1365-2745.12144

Memmott J, Craze PG, Waser NM, Price MV (2007) Global warming and the disruption of plant-pollinator interactions. Ecol Lett 10:710-717. https://doi.org/10.1111/j.1461-0248.2007.01061 .x

Mevi-Schütz J, Erhardt A (2005) Amino acids in nectar enhance butterfly fecundity: a long awaited link. Am Nat 165:411-419. https://doi.org/10.1086/429150

Miller-Rushing AJ, Primack RB (2008) Global warming and flowering times in Thoreau's Concord: a community perspective. Ecology 89:332-341

Miller-Rushing AJ, Høye TT, Inouye DW, Post E (2010) The effects of phenological mismatches on demography. Philos Trans R Soc B 365:3177-3186. https://doi.org/10.1098/rstb.2010.0148

Mountford J, Lakhani K, Kirkham F (1993) Soil seed bank composition in relation to the above-ground vegetation in fertilized and unfertilized hay meadows on a Somerset peat moor. J Appl Ecol 30:321-332

Muñoz AA, Celedon-Neghme C, Cavieres LA, Arroyo MTK (2005) Bottom-up effects of nutrient availability on flower production, pollinator visitation, and seed output in a high-Andean shrub. Oecologia 143:126-135. https://doi.org/10.1007/s0044 2-004-1780-3

Nepi M (2014) Beyond nectar sweetness: the hidden ecological role of non-protein amino acids in nectar. J Ecol 102:108-115. https ://doi.org/10.1111/1365-2745.12170

Nepi M, Soligo C, Nocentini D et al (2012) Amino acids and protein profile in floral nectar: much more than a simple reward. Flora 207:475-481. https://doi.org/10.1016/j.flora.2012.06.002

Newbould P (1989) The use of nitrogen fertiliser in agriculture. Where do we go practically and ecolitically? Plant Soil 115:297-311. https://doi.org/10.1007/BF02202596

Nijssen ME, WallisDeVries MF, Siepel H (2017) Pathways for the effects of increased nitrogen deposition on fauna. Biol Conserv 212:423-431. https://doi.org/10.1016/j.biocon.2017.02.022

Nilsson LA (1998) Deep flowers for long tongues. Trends Ecol Evol 13(259):260. https://doi.org/10.1016/S0169-5347(98)01359-7

Öckinger E, Hammarstedt O, Nilsson SG, Smith HG (2006) The relationship between local extinctions of grassland butterflies and increased soil nitrogen levels. Biol Conserv 128:564-573. https://doi.org/10.1016/j.biocon.2005.10.024

Ollerton J (2017) Pollinator diversity: distribution, ecological function, and conservation. Annu Rev Ecol Evol Syst. https://doi. org/10.1146/annurev-ecolsys-110316-022919

Ollerton J, Winfree R, Tarrant S (2011) How many flowering plants are pollinated by animals? Oikos 120:321-326. https://doi.org /10.1111/j.1600-0706.2010.18644.x

Ovaskainen O, Skorokhodova S, Yakovleva M et al (2013) Community-level phenological response to climate change. Proc Natl Acad Sci USA 110:13434-13439. https://doi.org/10.1073/ pnas. 1305533110 
Paoli PP, Donley D, Stabler D et al (2014) Nutritional balance of essential amino acids and carbohydrates of the adult worker honeybee depends on age. Amino Acids 46:1449-1458. https ://doi.org/10.1007/s00726-014-1706-2

Patiny S, Rasmont P, Michez D (2009) A survey and review of the status of wild bees in the West-Palaearctic region. Apidologie 40:313-331. https://doi.org/10.1051/apido/2009028

Petanidou T (2005) Sugars in Mediterranean floral nectars: an ecological and evolutionary approach. J Chem Ecol 31:1065-1088. https ://doi.org/10.1007/s10886-005-4248-y

Petanidou T, Van Laere A, Ellis WN, Smets E (2006) What shapes amino acid and sugar composition in Mediterranean floral nectars? Oikos 115:155-169. https://doi.org/10.111 1/j.2006.0030-1299.14487.x

Phoenix GK, Hicks WK, Cinderby S et al (2006) Atmospheric nitrogen deposition in world biodiversity hotspots: the need for a greater global perspective in assessing $\mathrm{N}$ deposition impacts. Glob Chang Biol 12:470-476. https://doi.org/10.111 1/j.1365-2486.2006.01104.x

Phoenix GK, Emmett BA, Britton AJ et al (2012) Impacts of atmospheric nitrogen deposition: responses of multiple plant and soil parameters across contrasting ecosystems in long-term field experiments. Glob Chang Biol 18:1197-1215. https://doi.org/1 0.1111/j.1365-2486.2011.02590.x

Potts SG, Vuliiamy B, Dafni A et al (2003) Linking bees and flowers: how do floral communities structure pollinator communities? Ecology 84:2628-2642

Potts SG, Biesmeijer JC, Kremen C et al (2010) Global pollinator declines: trends, impacts and drivers. Trends Ecol Evol 25:345353. https://doi.org/10.1016/j.tree.2010.01.007

Pöyry J, Carvalheiro LG, Heikkinen RK et al (2017) The effects of soil eutrophication propagate to higher trophic levels. Glob Ecol Biogeogr 26:18-30. https://doi.org/10.1111/geb.12521

Rader R, Bartomeus I, Garibaldi LA et al (2016) Non-bee insects are important contributors to global crop pollination. PNAS 113:146-151. https://doi.org/10.1073/pnas.1517092112

Richardson LL, Adler LS, Leonard AS et al (2015) Secondary metabolites in floral nectar reduce parasite infections in bumblebees. Proc R Soc B 282:20142471. https://doi.org/10.1098/ rspb.2014.2471

Richardson LL, Bowers MD, Irwin RE (2016) Nectar chemistry mediates the behavior of parasitized bees: consequences for plant fitness. Ecology 97:325-337. https://doi.org/10.1890/15-0263.1

RoTAP (2012) Review of transboundary air pollution

Roulston TH, Cane JH (2000) Pollen nutritional content and digestibility for animals. Plant Syst Evol 222:187-209. https://doi. org/10.1007/BF00984102

Roulston TH, Cane JH, Buchmann SL (2000) What governs protein content of pollen: pollinator preferences, pollen-pistil interactions, or phylogeny? Ecol Monogr 70:617-643. https ://doi.org/10.1890/0012-9615(2000)070\%5b0617:WGPCO $\mathrm{P} \% 5 \mathrm{~d} 2.0 . \mathrm{CO} ; 2$

Rundlöf M, Andersson GKS, Bommarco R et al (2015) Seed coating with a neonicotinoid insecticide negatively affects wild bees. Nature 521:77-80. https://doi.org/10.1038/nature14420

Rusterholtz HP, Erhardt A (2000) Can nectar properties explain sexspecific flower preferences in the Adonis Blue butterfly Lysandra bellargus? Ecol Entomol 25:81-90

Scheper J, Reemer M, van Kats R et al (2014) Museum specimens reveal loss of pollen host plants as key factor driving wild bee decline in The Netherlands. Proc Natl Acad Sci USA 111:1755217557. https://doi.org/10.1073/pnas. 1412973111

Scheu S (2001) Plants and generalist predators as links between the below-ground and above-ground system. Basic Appl Ecol 13:313. https://doi.org/10.1078/1439-1791-00031
Schoukens H (2017) Nitrogen deposition, habitat restoration and the EU habitats directive: moving beyond the deadlock with the Dutch programmatic nitrogen approach? Biol Conserv 212:484492. https://doi.org/10.1016/j.biocon.2017.02.027

Sedivy C, Praz CJ, Müller A et al (2008) Patterns of host-plant choice in bees of the genus Chelostoma: the constraint hypothesis of host-range evolution in bees. Evolution (NY) 62:2487-2507. https://doi.org/10.1111/j.1558-5646.2008.00465.x

Sedivy C, Müller A, Dorn S (2011) Closely related pollen generalist bees differ in their ability to develop on the same pollen diet: evidence for physiological adaptations to digest pollen. Funct Ecol 25:718-725. https://doi.org/10.1111/j.1365-2435.2010.01828.x

Shiraishi A, Kuwabara M (1970) The effects of amino acids on the labellar hair chemosensory cells of the fly. J Gen Physiol 56:768782. https://doi.org/10.1085/jgp.56.6.768

Shuel RW (1956) Some aspects of the relation between nectar secretion and nitrogen, phosphorus, and potassium nutrition. Can J Plant Sci 37:220-236

Silvertown J, Poulton P, Johnston E et al (2006) The Park Grass Experiment 1856-2006: its contribution to ecology. J Ecol 94:801-814. https://doi.org/10.1111/j.1365-2745.2006.01145.x

Snaydon RW, Davies TM (1982) Rapid divergence of plant populations in response to recent changes in soil conditions. Evolution (N Y) 36:289. https://doi.org/10.2307/2408047

Stevens CJ, Dupr C, Dorland E et al (2010a) Nitrogen deposition threatens species richness of grasslands across Europe. Environ Pollut 158:2940-2945. https://doi.org/10.1016/j.envpol.2010.06.006

Stevens CJ, Thompson K, Grime JP et al (2010b) Contribution of acidification and eutrophication to declines in species richness of calcifuge grasslands along a gradient of atmospheric nitrogen deposition. Funct Ecol 24:478-484. https://doi.org/10.111 $1 / \mathrm{j} .1365-2435.2009 .01663 . x$

Stevens CJ, David TI, Storkey J (2018) Atmospheric nitrogen deposition in terrestrial ecosystems: its impact on plant communities and consequences across trophic levels. Funct Ecol. https://doi. org/10.1111/1365-2435.13063

Stoate C, Boatman ND, Borralho RJ et al (2001) Ecological impacts of arable intensification in Europe. J Environ Manage 63:337-365. https://doi.org/10.1006/jema.2001.0473

Storkey J, Macdonald AJ, Poulton PR et al (2015) Grassland biodiversity bounces back from long-term nitrogen addition. Nature 528:401-404. https://doi.org/10.1038/nature16444

Storkey J, Macdonald AJ, Bell JR, Clark IM, Gregory AS, Hawkins NJ, Hirsch PR, Todman LC, Whitmore AP (2016) Chapter one-the unique contribution of Rothamsted to ecological research at large temporal scales. Adv Ecol Res 55:3-42. https://doi.org/10.1016/ bs.aecer.2016.08.002

Strengbom J, Olofsson J, Witzell J, Dahlgren J (2003) Effects of repeated damage and fertilization on palatability of Vaccinium myrtillus to grey sided voles, Clethrionomys rufocanus. Oikos 103:133-141

Strengbom J, Englund G, Ericson L (2006) Experimental scale and precipitation modify effects of nitrogen addition on a plant pathogen. J Ecol 94:227-233. https://doi.org/10.111 1/j.1365-2745.2005.01073.x

Suding KN, Collins SL, Gough L et al (2005) Functional- and abundance-based mechanisms explain diversity loss due to $\mathrm{N}$ fertilization. Proc Natl Acad Sci USA 102:4387-4392. https://doi. org/10.1073/pnas.0408648102

Szczesna T (2006) Protein content and amino acid composition of bee-collected pollen from selected botanical origins. J Apic Sci 50:81-90

Thórhallsdóttir T (1998) Flowering phenology in the central highland of Iceland and the implications for climatic warming in the Arctic. Oecologia 114:43-49 
Throop HL, Lerdau MT (2004) Effects of nitrogen deposition on insect herbivory: implications for community and ecosystem processes. Ecosystems 7:109-133. https://doi.org/10.1007/s1002 1-003-0225-x

Tylianakis JM, Didham RK, Bascompte J, Wardle DA (2008) Global change and species interactions in terrestrial ecosystems. Ecol Lett 11:1351-1363. https://doi.org/10.111 1/j.1461-0248.2008.01250.x

Vanbergen AJ, Iniative IP (2013) Threats to an ecosystem service: pressures on pollinators. Front Ecol Environ 11:251-259. https ://doi.org/10.1890/120126

Vanderplanck M, Moerman R, Rasmont P et al (2014) How does pollen chemistry impact development and feeding behaviour of polylectic bees? PLoS ONE 9:e86209. https://doi.org/10.1371/journ al.pone.0086209

Vitousek PM, Aber JD, Howarth RW et al (1997) Human alteration of the global nitrogen cycle: sources and consequences. Ecol Appl 7:737-750

WallisDeVries MF, van Swaay CAM (2017) A nitrogen index to track changes in butterfly species assemblages under nitrogen deposition. Biol Conserv 212:448-453. https://doi.org/10.1016/j.bioco n.2016.11.029

Wallisdevries MF, Van Swaay CAM, Plate CL (2012) Changes in nectar supply: a possible cause of widespread butterfly decline. Curr Zool 58:384-391. https://doi.org/10.1093/czoolo/58.3.384

Wardhaugh CW (2015) How many species of arthropods visit flowers? Arthropod Plant Interact 9:547-565. https://doi.org/10.1007/ s11829-015-9398-4
Weiner CN, Werner M, Linsenmair KE, Blüthgen N (2014) Land-use impacts on plant-pollinator networks: interaction strength and specialization predict pollinator declines. Ecology 95:466-474. https://doi.org/10.1890/13-0436.1

Weiss SB (2009) Cars, cows, deposition grasslands for checkerspot butterflies: nitrogen management of nutrient-poor a threatened species. Conserv Biol 13:1476-1486. https://doi.org/10.104 6/j.1523-1739.1999.98468.x

Wesche K, Krause B, Culmsee H, Leuschner C (2012) Fifty years of change in Central European grassland vegetation: large losses in species richness and animal-pollinated plants. Biol Conserv 150:76-85. https://doi.org/10.1016/j.biocon.2012.02.015

Williams PH, Osborne JL (2009) Bumblebee vulnerability and conservation world-wide. Apidologie 40:367-387. https://doi. org/10.1051/apido/2009025

Winfree R, Bartomeus I, Cariveau DP (2011) Native pollinators in anthropogenic habitats. Annu Rev Ecol Evol Syst 42:1-22. https ://doi.org/10.1146/annurev-ecolsys-102710-145042

Xia J, Wan S (2013) Independent effects of warming and nitrogen addition on plant phenology in the Inner Mongolian steppe. Ann Bot 111:1207-1217. https://doi.org/10.1093/aob/mct079

Publisher's Note Springer Nature remains neutral with regard to jurisdictional claims in published maps and institutional affiliations. 